\title{
Exceptional preservation of Cretaceous biota (plants and invertebrates) in flint-bearing alterites from Moragne (western France)
}

\author{
Jean-David Moreau, Didier Néraudeau, Roch-Alexandre Benoit, \\ Eric Dépré, Matthieu Le Couls, and Vincent Fernandez
}

\begin{abstract}
Cretaceous fossil inclusions were recently discovered in silica-rich nodules from the diachronic alteritic deposits of the Moragne hill, Charente-Maritime, western France. Nodules contain marine organisms such as sponge spicules, putative algae, echinoids (Periaster undulatus Agassiz and Desor) and rudists (Sphaerulites foliaceus Lamarck; hippuritids and radiolitids). These inclusions co-occur with fragmented pinnae of ferns as well as diverse structures of conifers including leafy axes (Geinitzia sp.; Glenrosa carentonensis Moreau, Néraudeau, Tafforeau and Dépré) and isolated ovulate scales or subtending bracts of cones. The palaeontological assemblage shows that the alterites from Moragne are condensed deposits resulting from the alteration of the Cenomanian to Turonian-Senonian regional series. Conifer leafy axes display diverse kinds of preservation: permineralization in silica, empty external casts of the gross morphology, and casts filled by ferruginous siltstone. Propagation phase-contrast X-ray synchrotron microtomography revealed exceptional preservation of some leafy axes up to the cell level. We support a multi-phase silicification including at least: (1) a precocious phase occurring during the sedimentation of the Upper Cretaceous deposits or during the earliest diagenesis, and that could be linked with the abundance of sponge spicules; then (2) a late phase occurring during Eocene-Oligocene period that corresponds to a hard climate event with strong and long paedogenitic alteration associated with an important phase of silicification (nodulation). The alterites from Moragne are an uncommon example of long-term time-averaged deposits caused by compaction and selective dissolution of matrix in the context of a late continental weathering.
\end{abstract}

Jean-David Moreau. CNRS UMR 6538 Laboratoire Géosciences Océan, Université Bretagne Sud, Centre de Recherche Yves Coppens, Campus de Tohannic, rue André Lwoff, 56017 Vannes, France.

jean.david.moreau@gmail.com

Didier Néraudeau. Géosciences Rennes, UMR 6118 CNRS, Université de Rennes 1, avenue du Général Leclerc, 35042 Rennes cedex, France. didier.neraudeau@univ-rennes1.fr

Moreau, Jean-David, Néraudeau, Didier, Benoit, Roch-Alexandre, Dépré, Eric, Le Couls, Matthieu, and Fernandez, Vincent. 2019. Exceptional preservation of Cretaceous biota (plants and invertebrates) in flint-bearing alterites from Moragne (western France). Palaeontologia Electronica 22.3.66 1-14. https://doi.org/10.26879/925

palaeo-electronica.org/content/2019/2754-fossiliferous-flints

Copyright: October 2019 Paleontological Society.

This is an open access article distributed under the terms of Attribution-NonCommercial-ShareAlike 4.0 International (CC BY-NC-SA 4.0 ), which permits users to copy and redistribute the material in any medium or format, provided it is not used for commercial purposes and the original author and source are credited, with indications if any changes are made.

creativecommons.org/licenses/by-nc-sa/4.0/ 
Roch-Alexandre Benoit. Géosciences Rennes, UMR 6118 CNRS, Université de Rennes 1, avenue du Général Leclerc, 35042 Rennes cedex, France. roch-alexandre.benoit@laposte.net

Eric Dépré. GIP-GEVES (Groupement d'Etude et de Contrôle des Variétés et Semences), Le Magneraud, 17700 Surgères, France. eric.depre@geves.fr

Matthieu Le Couls. Géosciences Rennes, UMR 6118 CNRS, Université de Rennes 1, avenue du Général Leclerc, 35042 Rennes cedex, France.matthieu.lecouls@wanadoo.fr

Vincent Fernandez. Imaging and Analyses Centre, Natural History Museum, Cromwell Road, SW7 5BD London, UK. vinfernand@gmail.com

Keywords: Upper Cretaceous; flints; silicification; time-averaging; fossil plants; X-ray synchrotron microtomography; France

Submission: 7 September 2018. Acceptance: 16 September 2019.

\section{INTRODUCTION}

To determine the age and origins of flint-bearing alterites is commonly problematic because they can result from the erosion and condensation of diverse geological units, and are sometimes diachronic (Dewolf, 1970; Daniou, 1982, 1984). Locally, such superficial deposits contain silica-rich nodules that yield abundant fossil inclusions whose stratigraphic origins and preservation are precious tools to discuss the genesis of alterites. In France, whereas Cretaceous marine invertebrates (brachiopods, bivalves, bryozoans, echinoids, sponges) are common inside flint from alterites (e.g., Néraudeau 2004, 2011; Caux, 2015), terrestrial floras remain extremely rare. Over the last decades, alterites containing fossiliferous flints with Upper Cretaceous plant macroremains were discovered from few localities in western France: the Font-Benon quarries in Charente-Maritime (Moreau et al., 2014a); Claix and Torsac in Charente (Néraudeau, 2014; Moreau et al., 2016); and three areas around Châtellerault in Vienne (Moreau et al., 2018). By contrast with most of Cretaceous plant beds from western France which preserved foliar remains as impressions or compressions with or without cuticle (e.g., Lecointre and Carpentier, 1938; Alvarez-Ramis et al., 1981; Berthelin and Pons, 1999; Néraudeau et al., 2005, 2012; Saint-Martin et al., 2013; Valentin et al., 2014), flints may contain exquisite siliceous preservations of the plant macroremains up to the cell levels.

Recently, flint nodules containing Cretaceous terrestrial plant inclusions and marine invertebrates were discovered in alterites from the village of Moragne, in Charente-Maritime. In order to discuss age and origin of the alterites, we describe the palaeontological assemblage of nodules and its preservation. X-ray synchrotron microtomography is used to determine the degree of preservation of plant macroremains and to characterize their histology.

\section{GEOGRAPHICAL AND GEOLOGICAL SETTING}

The study area is located in the northern part of the Aquitaine Basin at Moragne, $14 \mathrm{~km}$ east of Rochefort (Charente-Maritime department, southwestern France). The Moragne area consists of a small hill of lower Cenomanian sandstone and clay, which are overlain by Palaeogene alteritic deposits (Bourgueil et al., 1972; Figure 1). Regionally, Cretaceous deposits lie unconformably on the Late Jurassic limestone deposits that constitute the outcrops around the Moragne hill (Figure 1). The fossiliferous flints studied here were all collected in the Eocene-Oligocene residual formation that constitutes the top of the hill and is mainly composed of gravel, sand, silt, and clay. At Moragne, the formation yielding fossiliferous flints are not well developed being limited to a small area of less than 800 $\mathrm{m}$ in diameter and $50 \mathrm{~cm}$ to some metres in thickness. Alterites yield abundant yellow, orange, red to brown flints.

\section{MATERIALS AND METHODS}

Plant inclusions from the fossiliferous flints of Moragne were first observed by one of us (ED) in 2013. Thousands of flints were examined and hundreds of fossiliferous flints were collected on surfaces of agricultural fields between 2013 and 2018. Only some of them bear plant inclusions. Plant remains consist of fragmented pinnae of ferns, leafy axes and isolated scales of cones of conifers, and wood (Figures 2-5). Wood fragments are found isolated in alteritic deposits whereas leafy axes are present on the broken surfaces or inside flints. Size of wood fragments varies from several centimetres 


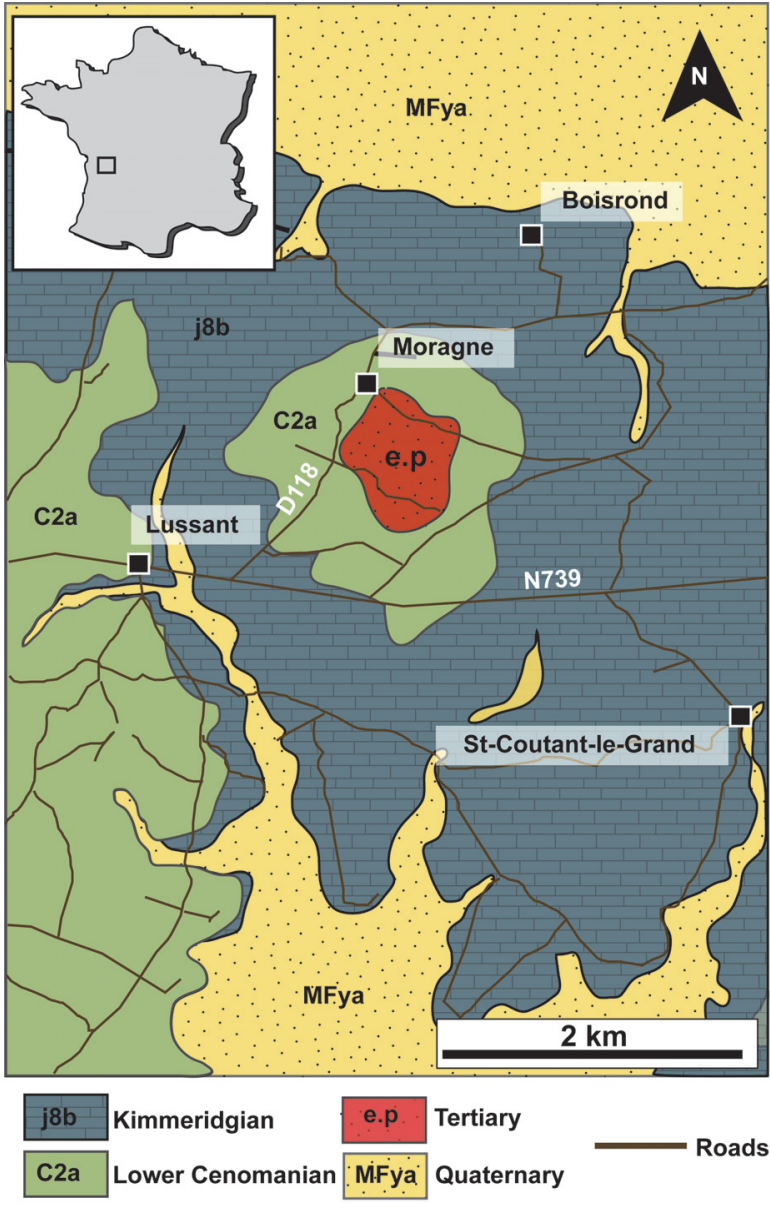

FIGURE 1. Geological map of the Moragne area in Charente-Maritime (western France). Modified after Bourgueil et al. (1972).

to more than $3 \mathrm{dm}$. Plant-bearing flints are irregular in shape and do not exceed $25 \mathrm{~cm}$ in diameter. The plant inclusions consist of macroremains dispersed inside the flint matrix and do not form rich accumulations. Although plants are all preserved in 3D or slightly compressed, preservation is not homogeneous (Figure 3 ). Some specimens are completely permineralized in silica, preserving most of tissues. On surface of broken flints, some plant remains consist of replicas showing external casts filled by orange ferruginous siltstone, whereas more rarely external casts are empty. In some cases, specimens display a combination of these diverse kinds of preservation. Plant remains co-occur with oxidized and silicified marine organisms in the lateritic deposits and sometimes inside reddish flints. The flints are housed in the collection of Géosciences Rennes, CNRS UMR 6118, Université Rennes 1 (Rennes, France).
Propagation phase-contrast $\mathrm{X}$-ray synchrotron microtomography (PPC-SR $\mu \mathrm{CT}$ ) was used on the best preserved plant specimens and was efficient to characterize their histology. The flint nodules were characterized at beamline ID19 of the European Synchrotron Radiation Facility (ESRF, Grenoble France) using PPC-SR $\mu$ CT. The setup consisted of: filtered white beam with an effective energy of $125 \mathrm{keV}$ (wiggler W150b gap $35 \mathrm{~mm}, 6$ $\mathrm{mm}$ coper filter); sample-detector propagation distance of $100 \mathrm{~cm}$; an indirect detector comprising a $200 \mu \mathrm{m}$ LuAG scintillator, 3x magnification from a set of Hasselblad lenses and a PCO edge 4.2 detector, producing data with an isotropic voxel size of $2.26 \mu \mathrm{m}$. The acquisition consisted of 6000 projections ( $0.01 \mathrm{~s}$ exposure time) over $360^{\circ}$, with an offset on the centre of rotation to increase the lateral field of view. The reconstruction was performed with PyHST2 (Mirone et al., 2014), using single distance phase retrieval (Paganin et al., 2002) and an unsharp mask to limit the induced blurring (Sanchez et al., 2012). Data were finally converted into a 16 bit tiff stack of slices $(0.001 \%$ exclusion of the 32 bits 3D histogram), corrected for residual ring artefacts (Lyckegaard et al., 2011) and cropped. The three-dimensional (3D) reconstructions of specimens were achieved with the software VG Studio Max 2.2 (Volume Graphics, Heidelberg, Germany). The virtual dissection and segmentation were made using $3 \mathrm{D}$ region growing and manual selections.

\section{SYSTEMATIC PALAEOBOTANY}

\section{Order FILICALES Bower, 1899 \\ Filicales indet. "Fern Type 1" \\ Figure 2}

Material. 1 specimen, IGR-PAL-2782.

Description. The specimen displays three distal fragments of pinnae. The largest pinna fragment is $7 \mathrm{~mm}$ long and $5 \mathrm{~mm}$ wide. The pinna consists of a rachis bearing sub opposite, scythe-shaped, up to 3.5 long and $2 \mathrm{~mm}$ wide pinnules (Figure 2). They are attached by a broad base to the rachis and display an acute apex and an entire margin. The rachis is less than $1 \mathrm{~mm}$ wide.

Remarks. Ferns correspond to the less abundant remains in the silicified flora from Moragne. Because of a limited preservation, the veins cannot be distinguished.

\section{Order CONIFERALES Gorozhankin, 1904}

Genus GEINITZIA Endl., 1847

\section{Geinitzia sp.}

Figure 3 


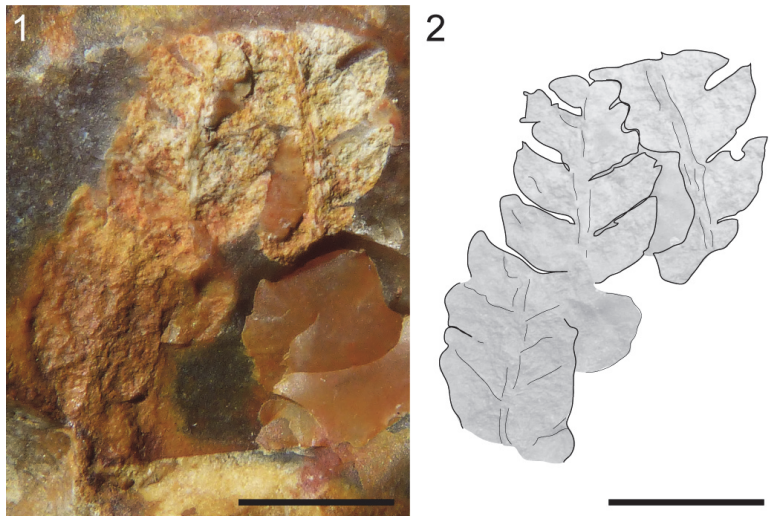

FIGURE 2. 1-2, Pinnae of Filicales indet. "Fern Type 1" bearing sub opposite falciform pinnules attached by a broad base to the rachis (1) and interpretative sketch (2) (IGR-PAL-2782). All scale bars equal $0.5 \mathrm{~mm}$.

Material. 21 specimens, IGR-PAL-2783- IGRPAL-2794, IGR-PAL-2795a, IGR-PAL-2795b, IGRPAL-2796-IGR-PAL-2803.

Description. The longest specimen is $70 \mathrm{~mm}$. Branches arise at up to $45^{\circ}$. Shoots are up to 18 $\mathrm{mm}$ in diameter, strait to slightly curve. Leaves are helically arranged. They are elongated, up to 21 $\mathrm{mm}$ long and $2.5 \mathrm{~mm}$ wide (Figure 3 ). Leaves show a long free part that forms an acute angle of up to $70^{\circ}$ with main axis of the shoot. The leaf margin is entire. The apex of leaves is acute and slightly curved inward. In cross section, leaves are quadrangular in shape.

Remarks. Leafy axes of Geinitzia are the most abundant plant remains from the silicified flora of Moragne. Elongated, lanceolate, helically arranged leaves forming an acute angle with the main axis of the shoots are known among several Cretaceous conifers such as Cunninghamites Presl in Sternberg, 1838, Elatocladus T.Halle, 1913, Geinitzia and Pagiophyllum Heer emend. T.M.Harris, 1979. The genus Geinitzia differs from Elatocladus by the absence of contraction at the leaf base (Kvaček, 1999). Leaves of Geinitzia differ from Cunninghamites in having a triangular to quadrangular form in cross section, not needles flattened (Kvaček, 1999; Herman and Kvaček, 2010).

Genus GLENROSA J.Watson and H.L.Fisher, 1984 emend. Srinivasan, 1992

Glenrosa carentonensis Moreau, Néraudeau, Tafforeau and Dépré, 2015 Figure 4

Material. 1 specimen IGR-PAL-2804.

Description. Leafy axis is unbranched, $10.0 \mathrm{~mm}$ long and $4.5 \mathrm{~mm}$ wide (Figure 4.1-3). Leaves are helically arranged, short, up to $3 \mathrm{~mm}$ long and up to
$1.5 \mathrm{~mm}$ wide. They are triangular in abaxial and adaxial views, rhomboidal in transversal section, claw-shaped in sagittal section (Figure 4.4-6). Their margin is entire. Apex of leaves is obtuse (Figure 4.1-6). Abaxial and adaxial surface of leaves bear putative deep stomatal crypts (Figure 4.7). Crypts are generally as wide as deep, or slightly deeper than wide. Putative stomatal crypts are up to $80-110 \mu \mathrm{m}$ in diameter and $60-140 \mu \mathrm{m}$ deep (Figure 4.7). Cuticle is only partially preserved been often torn and up to $13 \mu \mathrm{m}$ thick. Adaxial epidermis is $12-40 \mu \mathrm{m}$ thick (Figure 4.8). Ordinary epidermal cells are square, rectangular, or polygonal, being 10-55 $\mu \mathrm{m}$ of wide. Palisade parenchyma consists of one layer (rarely two) of elongated cells (Figure 4.4). Palisade parenchyma occurs on both sides but is mainly developed on the adaxial side. It develops along the entire leaf length. Cells are 35-110 $\mu \mathrm{m}$ long and 30-60 $\mu \mathrm{m}$ wide. Anticlinal walls are curve to straight. Spongy parenchyma is well-developed both on abaxial and adaxial sides (Figure 4.4-6). Spongy parenchyma is thinner toward to the leaf apex and absent on this latter. Spongy parenchyma consists of large and rounded cells. Cells vary in size, being 15-130 $\mu \mathrm{m}$ in diameter. The anticlinal walls are curve. Transfusion tissue occurs on the abaxial side and is up to $200 \mu \mathrm{m}$ thick (Figure 4.4-6). Transfusion tracheids are slightly elongate and ovoid to polygonal. Transfusion tracheids are 25-100 $\mu \mathrm{m}$ long and 10-45 $\mu \mathrm{m}$ wide. A single vascular bundle ends before the leaf apex (Figure 4.4-6). Vascular bundle forms an angle of up to $45^{\circ}$ with the stem. Vascular bundle is up to $1.5 \mathrm{~mm}$ long, up to $120 \mu \mathrm{m}$ wide (Figure 4.4-6). Vascular bundle is basally embedded in transfusion tissue.

Remarks. Due to the poor preservation of some parts of the specimen and technical limits of the tomographic protocol, papillae from crypts (see Moreau et al., 2015), stomata, hypodermis, and details of vascular cylinder are not accessible. The genus Glenrosa is represented by seven species that are Barremian to Turono-Coniacian in age (e.g., Watson and Fisher, 1984; Srinivasan, 1992; Zhou et al., 2000; Moreau et al., 2015; Néraudeau et al., 2016). Glenrosa carentonensis highly differs from other species in developing a phyllotaxy 8/21, claw-shaped leaves, a thicker cuticle, and a higher number of papillae and stomata per crypt.

\section{Coniferales indet. "Scale/bract Type 1"}

Figure 5

Material. 1 specimen IGR-PAL-2795c

Description. The scale/bract is longer than wide (i.e., $6.5 \mathrm{~mm}$ long and $5.0 \mathrm{~mm}$ wide), convex, 


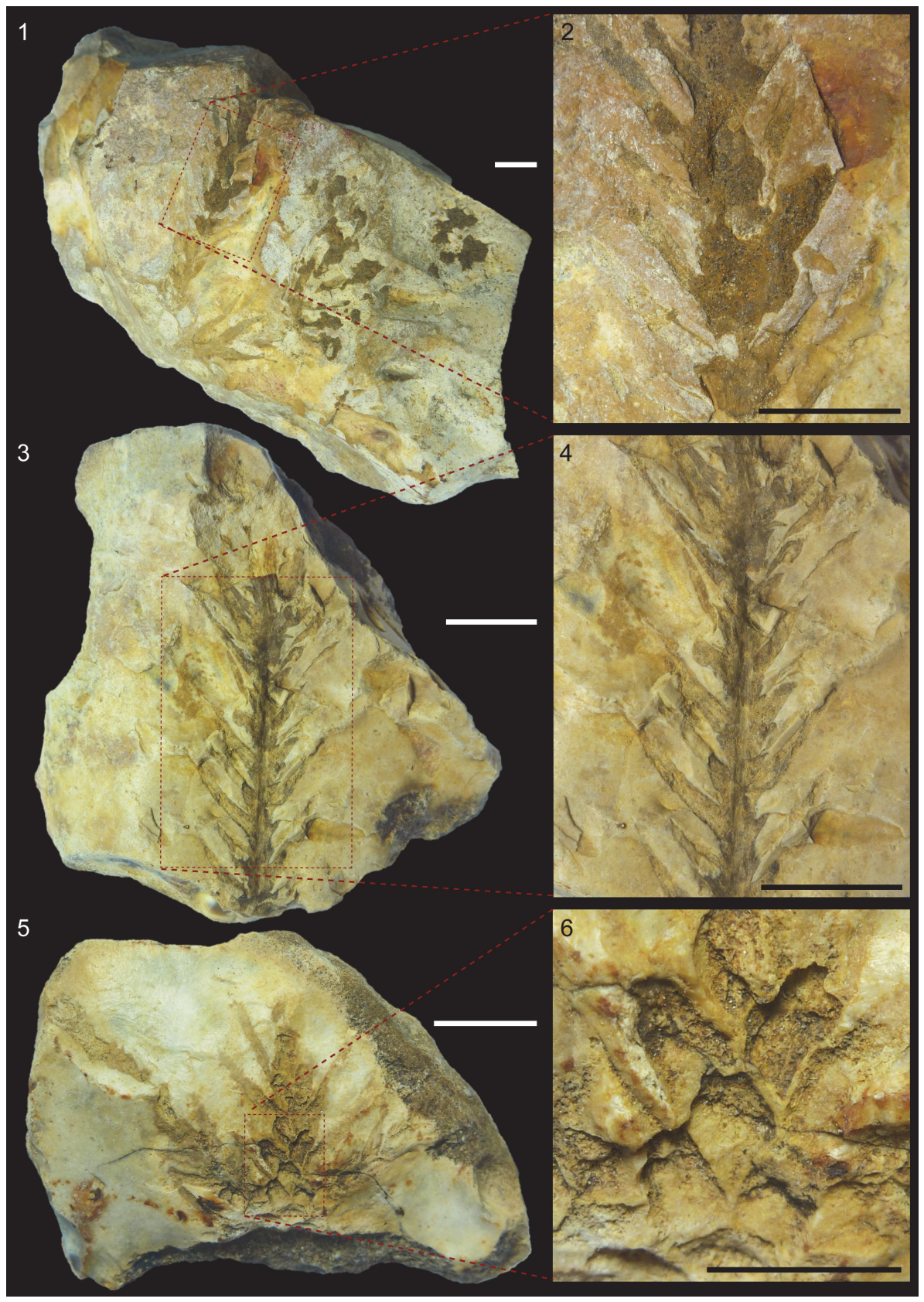

FIGURE 3. Flints from Moragne containing diverse preservations of the Upper Cretaceous conifer leafy axes Geinitzia $\mathrm{sp}$. which display shoots with helically arranged and elongated leaves. 1-2, Replica showing external cast filled by orange ferruginous siltstone, IGR-PAL-2783. 3-4, Permineralized in silica preserving inner microstructures, IGR-PAL2784. 5-6, Empty external cast, IGR-PAL-2785. Scale bars: 1-5, $1 \mathrm{~cm} ; \mathbf{6}, 0.5 \mathrm{~mm}$.

shows a broad truncate base, an acuminate apex and an entire margin (Figure 5.1-2). The apex displays a free tip ( $2 \mathrm{~mm}$ long and up to $1 \mathrm{~mm}$ wide) that bends upward. The visible adaxial surface displays a central, proximal, $3.0 \mathrm{~mm}$ long, and $0.5 \mathrm{~mm}$ wide, groove. The groove ends before the apical free tip.
Remarks. Due to a limited preservation, it is not clear that the specimen is an ovulate cone scale rather than its subtending bract. Some isolated ovulate cone scales preserved as impressions and compressions were previously reported from the lower Cenomanian of Charente-Maritime (e.g., Néraudeau et al., 2009). They were tentatively 

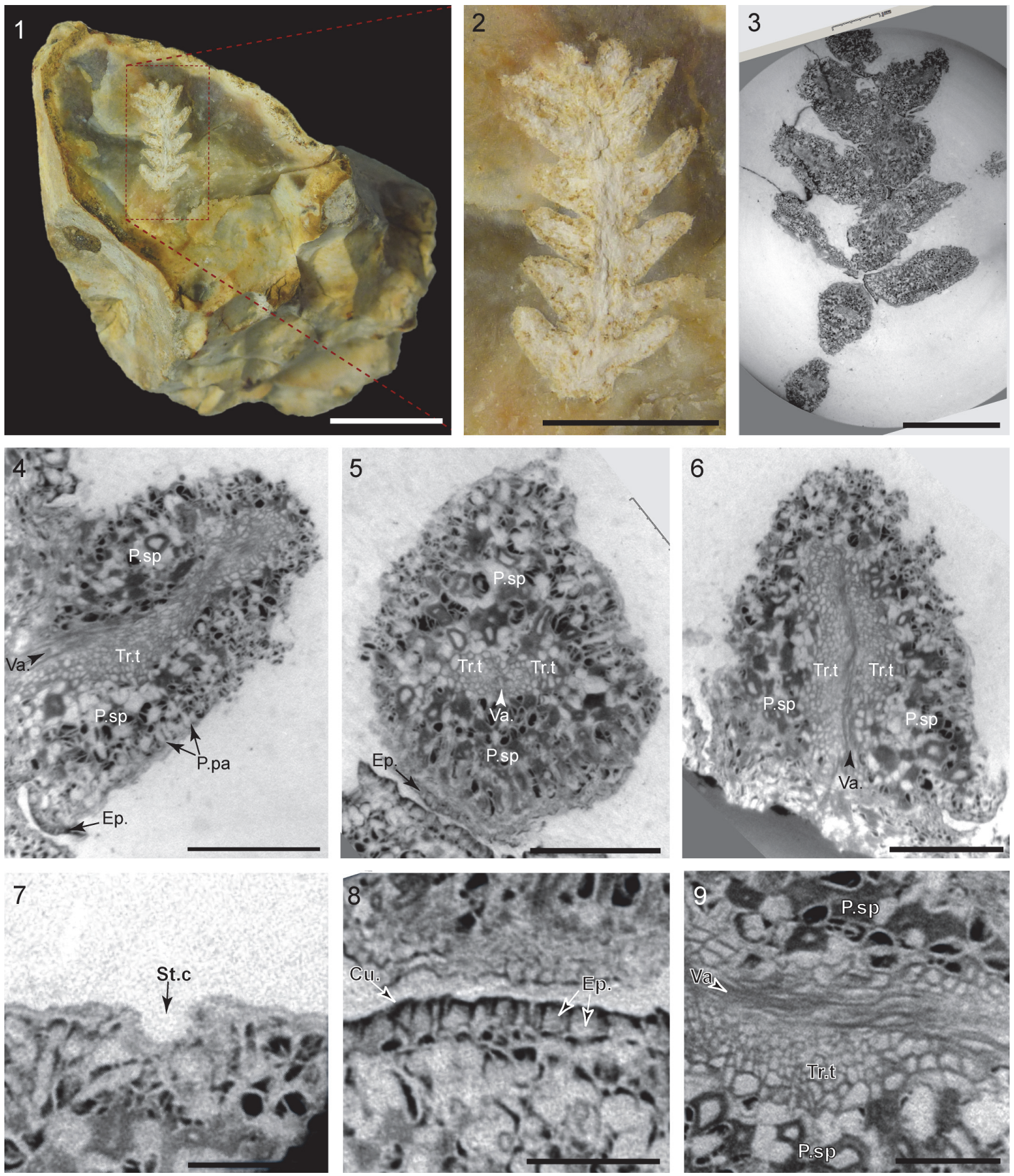

FIGURE 4. Flint from Moragne containing an Upper Cretaceous conifer leafy axis Glenrosa carentonensis which displays a shoot with helically arranged and short leaves, IGR-PAL-2804. 1-2, Photographs of the broke-open nodule and detail of the leafy axis. 3-9, X-ray synchrotron microtomography virtual histological sections showing preservation of all inner tissues; longitudinal section of the leafy axis (3); sagittal section of a leaf (4); transversal section of a leaf (5); tangential section of a leaf (6); uppermost adaxial surface of a leaf showing a putative stomatal crypt in transversal section (7); uppermost adaxial surface with cuticle, epidermis and hypodermis in transversal section (8); detail of vas-

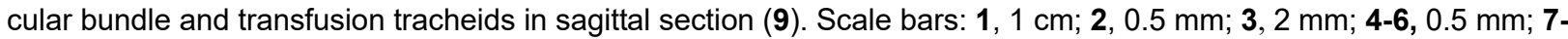
9, 0.2 mm. Abbreviations: Cu., cuticle; Ep., Epidermis; P.pa, palisade parenchyma; P.sp, spongy parenchyma; St.c, putative stomatal crypts; Tr.t, transfusion tracheids; Va., vascular bundle. Voxel size: 3-9, $2.26 \mu \mathrm{m}$. 

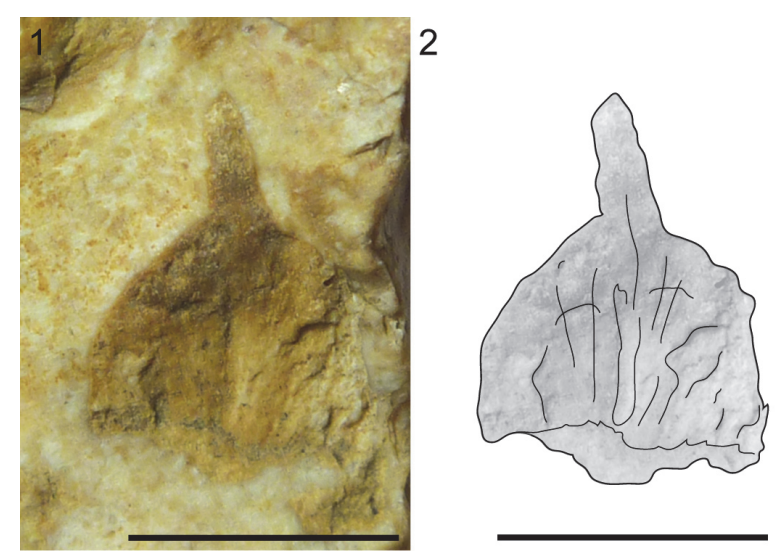

FIGURE 5. 1-2, Upper Cretaceous scale/bract Type 1 from Moragne (IGR-PAL-2795c) showing a broad truncate base, an acuminate apex and an entire margin (1), and interpretative sketch (2). Scale bars equal $0.5 \mathrm{~mm}$.

ascribed to Alvinia bohemica (Velenovský) Kvaček, 2000. However, the shape of the cone scale from Moragne strongly differs from these specimens. We notice that the gross morphology and the range size of the specimen from Moragne are close to those of the some bract scales of the Cretaceous Cheirolepidiaceae (e.g., Del Fueyo et al., 2008).

\section{OTHER ORGANISMS}

The most abundant marine invertebrate remains correspond to sponge spicules, with dozens to thousands of specimens preserved in a same flint nodule. Fragmented or complete rudists are the second most frequent silicified invertebrates. Fragments of the Cenomanian rudist Sphaerulites foliaceus Lamarck, 1819, are particularly abundant in the alterites but never found in the flints (Figure 6.1). In addition, four sub-complete rudists have been found in the lateritic deposits. The two best ones can be identified as large subcylindrical Hippurites sp. or Radiolites sp. (Figure 6.2-4), species that characterize deposits younger than Cenomanian in Charentes (Macé-Bordy, 2007; Néraudeau et al., 2013b). Five colonial corals close to Eosiderastrea sp. have been collected in the alterites, outside the flints (Figure 7.1). A single solitary coral, close to Aulosmilia sp. has been found (Figure 7.2). Three specimens of the large Cenomanian spatangoid echinoid Periaster undulatus Agassiz and Desor, 1847 have been collected, two in reddish flint nodules, the last one in the alterites (Figure 7.3-5).

Finally, the silicified wood from Moragne is sometimes perforated by large and long galleries likely made by the xylophagous bivalve Teredo sp.
These galleries have sometimes a blue opalescent colour that contrasts with the reddish oxidized colour of the fossil wood (Figure 6.5). The flints from Moragne yielded a single specimen of putative alga that superficially resemble Solenopora Dybowski, 1877 (Figure 8).

\section{DISCUSSION}

\section{Age of the Fossil Assemblage}

Geinitzia and Glenrosa were reported in many Albian to Turonian plant beds from western France (e.g., Néraudeau et al., 2005, 2009, 2016; Girard et al., 2013; Néraudeau, 2014; Moreau et al., 2015, 2017). Geinitzia was previously reported from the uppermost Albian of the Font-Benon and Les Renardières quarries (Charente-Maritime; Néraudeau et al., 2005; Moreau et al., 2017), the Cenomanian of the Puy-Puy and Le Brouillard quarries (Charente-Maritime and Maine-et-Loire respectively; Néraudeau et al., 2005, 2013a) and from the Turonian of Simeyrols (Dordogne; SaintMartin et al., 2013). In all these localities, specimens are preserved as compressions in marls with lignite. Only the Cenomanian flints of ArchingeayLes Nouillers (Moreau et al., 2014a), and those from the Turono-Coniacian of Claix previously yielded permineralized/petrified leafy axes of Geinitzia. In western France, cuticles of the conifer Glenrosa were previously reported from many Albian to Turono-Coniacian deposits from Aude, Charente, Charente-Maritime and Dordogne (see Moreau et al., 2017 and reference therein). After the silicified deposits from the Font-Benon quarries (Charente-Maritime), the flints from Moragne constitute the second occurrence worldwide yielding both Geinitzia and Glenrosa preserved as siliceous permineralization (Moreau et al., 2014a, 2014b, 2015).

The echinoid Periaster undulatus characterizes the upper part of the first marine lithological unit (B1 sensu Néraudeau et al., 1997; Néraudeau and Moreau, 1989) of the lower Cenomanian from northern Aquitaine (Néraudeau, 2012). The rudist Sphaerulites foliaceus is known in the lower and mid Cenomanian deposits from Charentes (Néraudeau et al., 2013b; Miramand et al., 2017). However, the hippuritid and radiolitid rudists indicate a younger age, late Turonian to Senonian.

Thus, although flints from the Moragne hill were previously and tentatively dated to Cenomanian (e.g., Laporte et al., 2000), this study demonstrates that the alterites consist of condensed deposits, which result from the alteration of Creta- 


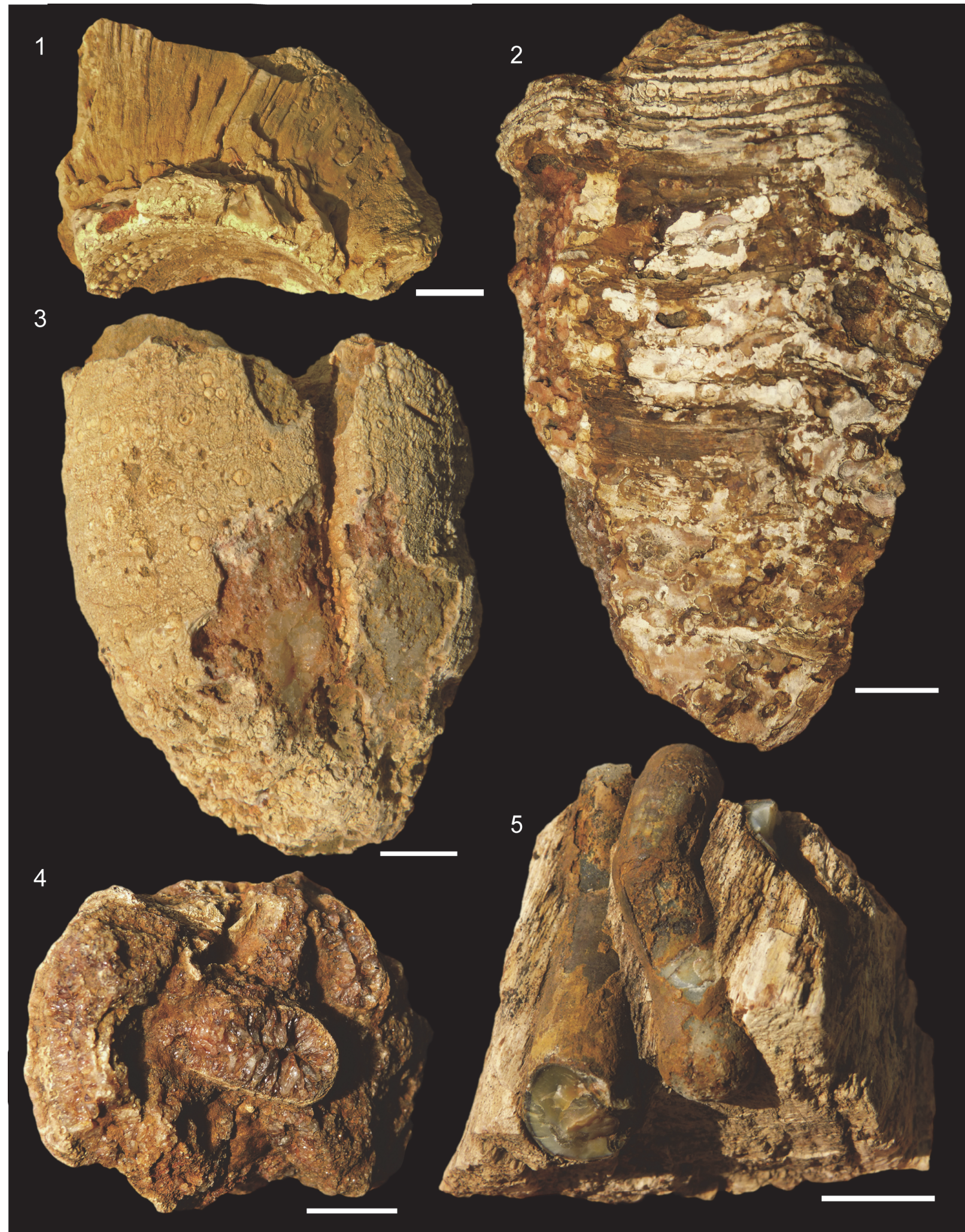

FIGURE 6. Upper Cretaceous silicified marine bivalves from the flints of Moragne. 1, Fragment of the Cenomanian rudist Sphaerulites foliaceus, IGR-PAL-2805. 2, Lateral view of radiolitid rudist, IGR-PAL-2806. 3, Lateral view of an hippuritid rudist, IGR-PAL-2807. 4, Top view of an hippuritid rudist showing the two alveoles, with quartz geodes, that correspond to the two teeth of the opercular valv, IGR-PAL-2808. 5, Piece of silicified wood with two galleries realized by the xylophagous bivalvia Teredo sp., IGR-PAL-2809. Scale bars equal $1 \mathrm{~cm}$. 


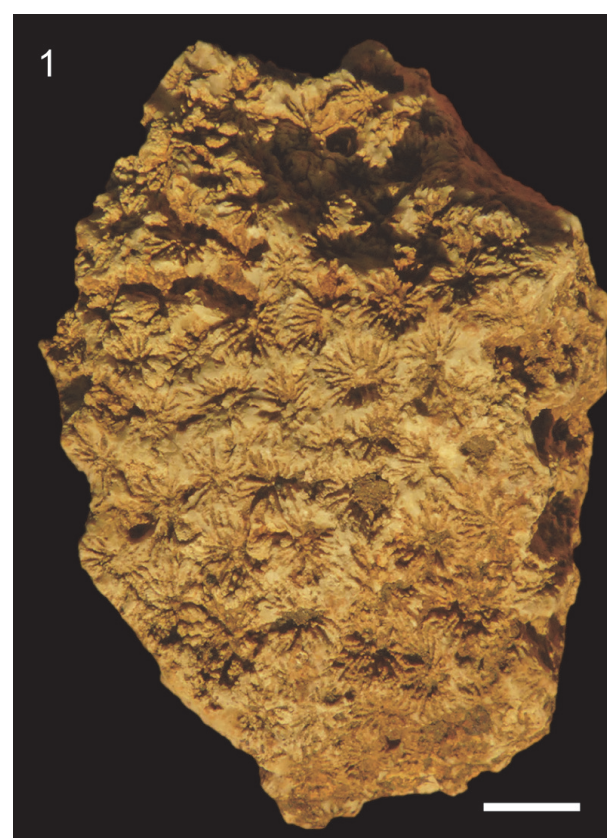

4

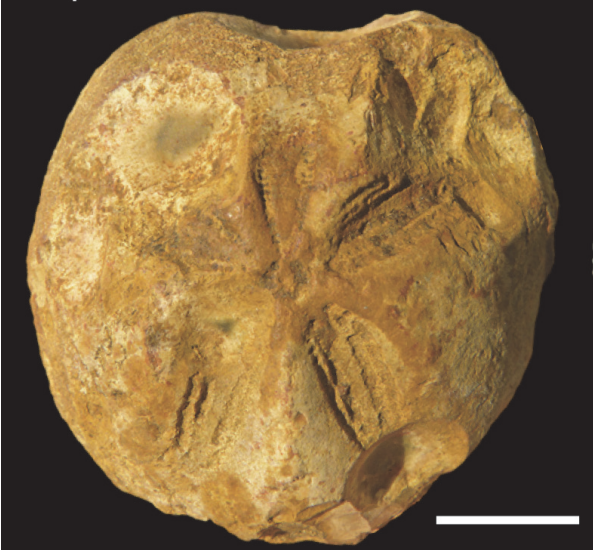

\section{2}

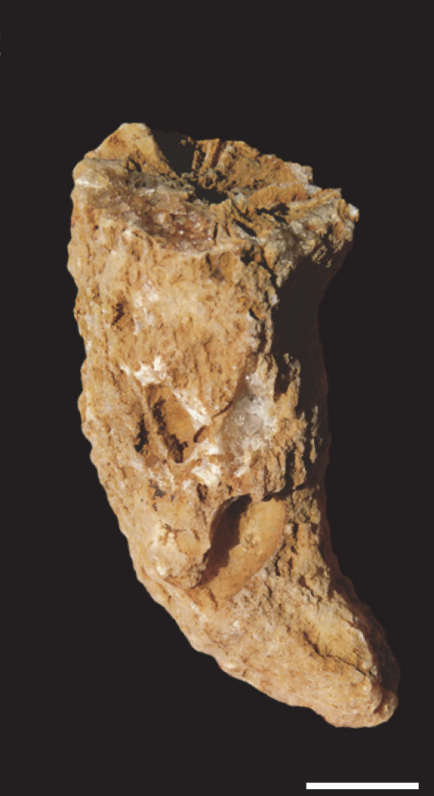

3

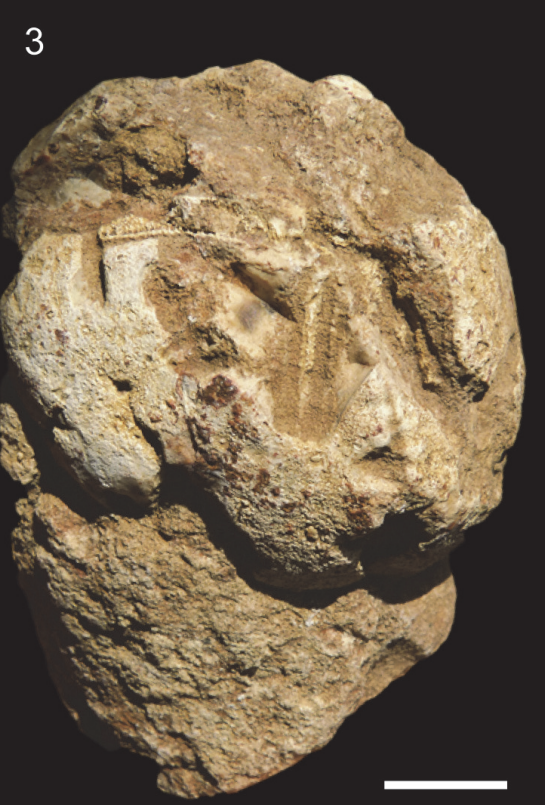

5

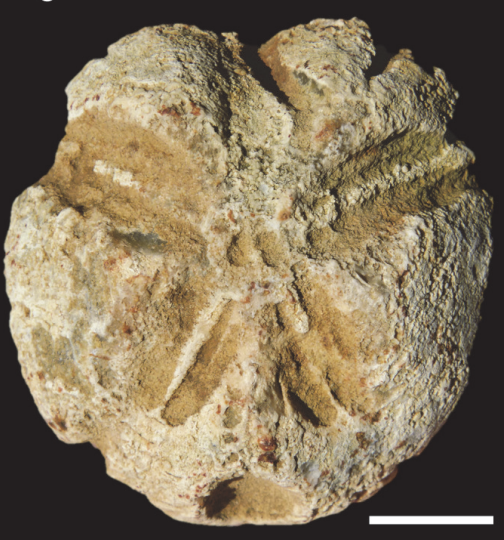

6

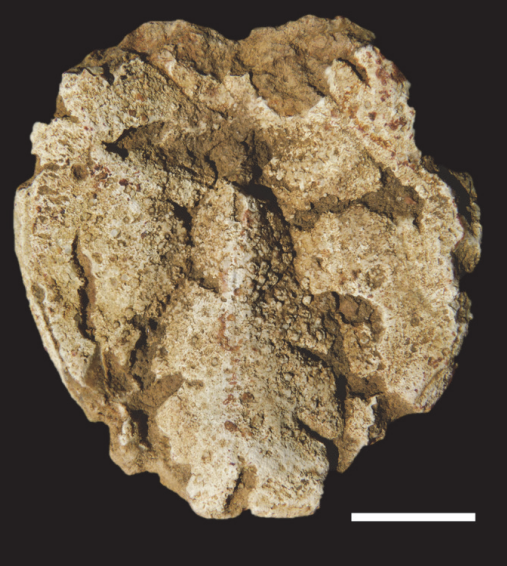

FIGURE 7. Upper Cretaceous silicified echinoids and Anthozoans from the flints of Moragne. 1, Colonial coral close to Eosiderastrea sp., IGR-PAL-2810. 2, Solitary coral close to Aulosmilia sp., IGR-PAL-2811. 3, Specimen of the spatangoid echinoid Periaster undulatus attached to a flint nodule by its adoral face, IGR-PAL-2812. 4, Periaster undulatus preserved in an oxidized reddish flint, IGR-PAL-2813. 5-6, Other specimen of $P$. undulatus from which adapical (5) and adoral (6) faces are preserved, IGR-PAL-2814. Scale bars equal $1 \mathrm{~cm}$.

ceous formations at least lower Cenomanian to Turonian-Senonian in age (Figure 9). At Moragne, several dozens of metres of the original Upper Cretaceous series finally correspond to only less than one to some metres of alteritic deposits bearing flints (Figure 9).

\section{Origin of the Alterites}

As well as in Moragne, other localities from Charente and Charente-Maritime show silicified deposits at the top of topography. It consists of diachronic silicification affecting all deposits independently to their age and lithology, from the Upper Jurassic to the lower-middle Eocene (e.g.,
Néraudeau, 2011; Daniou, 1978). The Eocene-Oligocene period is characterized by a hard climate episode with strong and long paedogenetic alteration associated to an important phase of silicification. Regionally, the phenomenon was tentatively explained by a kaolinization of surface deposits (see Moreau et al., 2014a, 2014b). Exposed rocks were dissolved and decalcified under the influence of soil leaching by meteoric waters during warm and wet climates (Gallois, 2009). As explained by Callen (1983) the dissolution and the re-deposition of silica commonly result from a climate change from wet to arid. Regionally, the top of alterite deposits yields flints containing upper Eocene-Oli- 


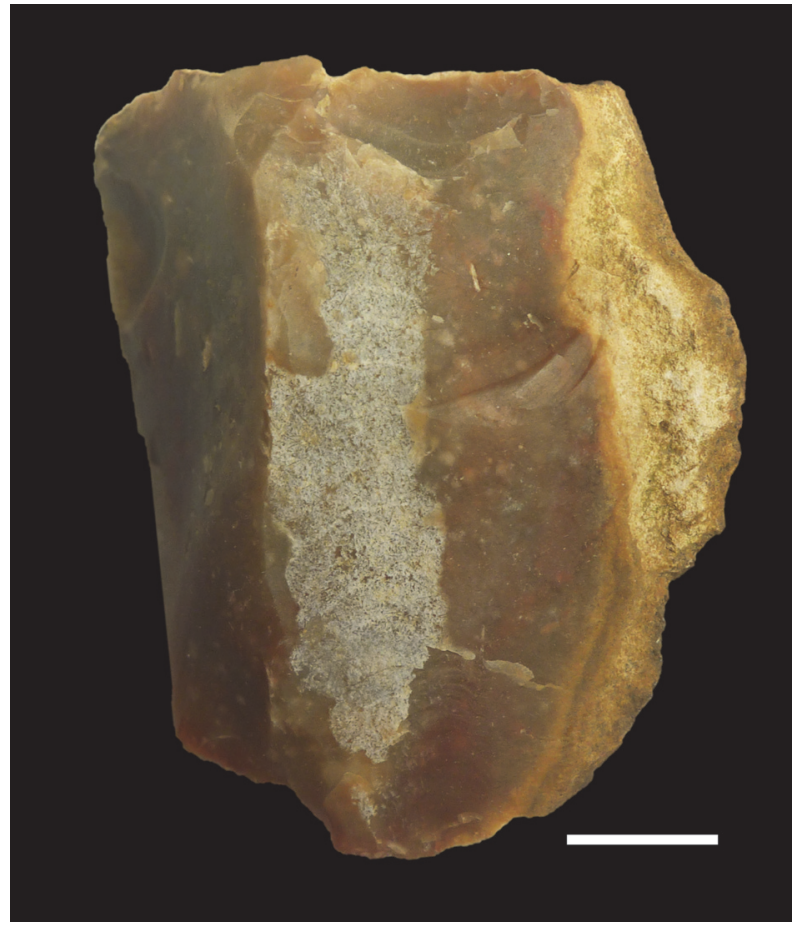

FIGURE 8. Fragment of flint from Moragne bearing a putative alga, IGR-PAL-2815. Scale bar equals $1 \mathrm{~cm}$.

gocene charophytes that characterize the end of the Palaeogene climatic event (DN and R-AB personal obs.).
Although a main silicification event occurred obviously during the late Palaeogene, it is not sufficient to explain the exquisite preservation of tissues and cells in 3D inside Late Cretaceous fossil plants. Such preservation is only possible when the mineralization of inner and intracellular spaces occurs precociously. The abundance of sponge spicules in the matrix of plant-bearing flints as well as on the surface of plant remains (see Figure 10) might has been a potential source of silica. Thus, the silicified fossil assemblage from the flints of Moragne supports a multi-phase silicification including: (1) at least a precocious phase occurring during the sedimentation of the Upper Cretaceous deposits or during the earliest diagenesis; (2) a late phase occurring during Eocene-Oligocene interval and explaining the nodulation leading to secondary flints. Such multi-phase silicification processes have been previously identified in several localities yielding plant-bearing flints from western France (Moreau, 2014b, 2017). The various kinds of plant preservation (empty casts, replicas by siltstone, permineralizations) among plant macro-remains show that silicification occurred heterogeneously, probably depending on the concentration of silicarich sponge spicules in the diverse sediments. Empty casts and replicas of leafy axes are not compressed but preserved in 3D. It confirms that plant remains, which were dissolved during the

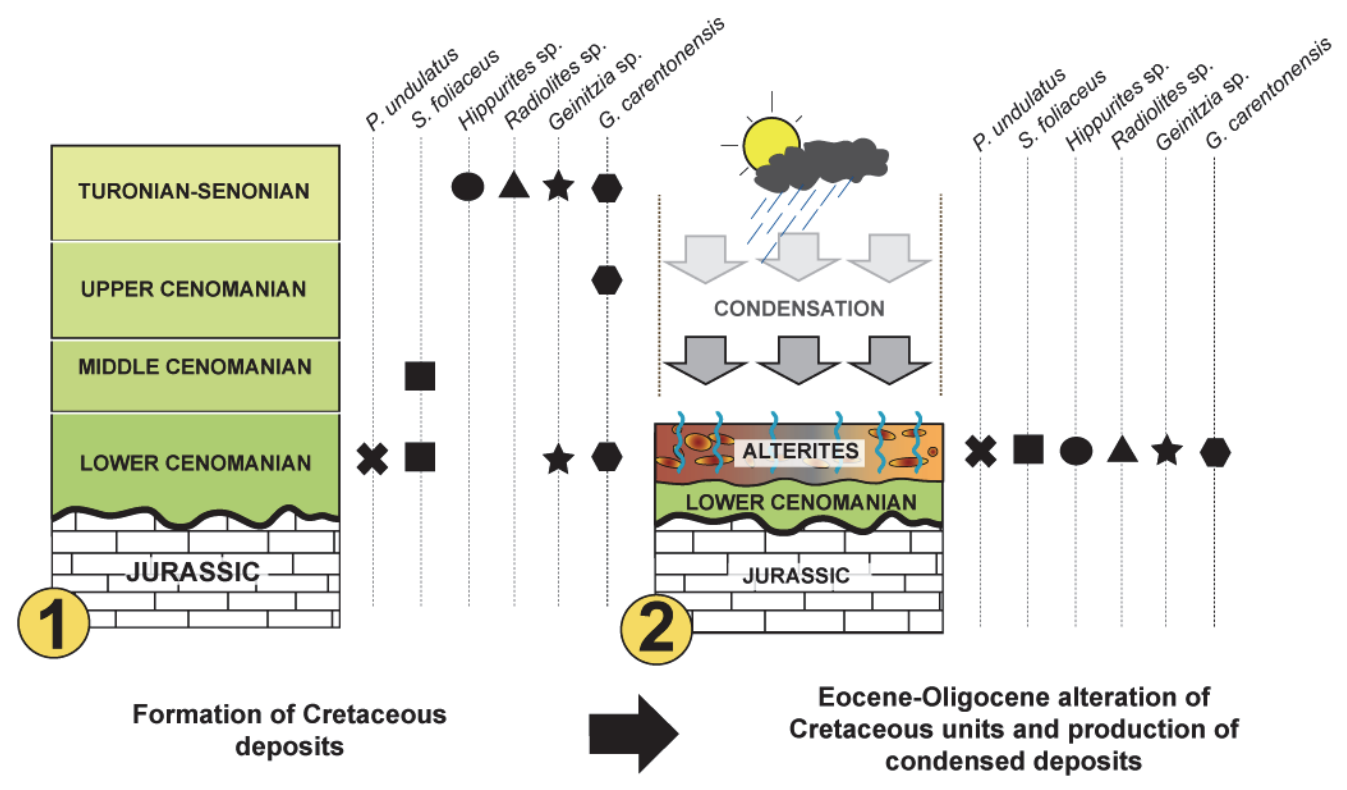

FIGURE 9. Synthetic sketches of the formation of the condensed alterites. 1, Formation of Cretaceous deposits and stratigraphic location of the fossils from the flints of Moragne in the Upper Cretaceous series of Charente and Charente-Maritime. 2, Alteration of Cretaceous units and production of condensed deposits (alterite containing flint nodules) during the Eocene-Oligocene alteration; location of the Upper Cretaceous fossils in the alterites. 


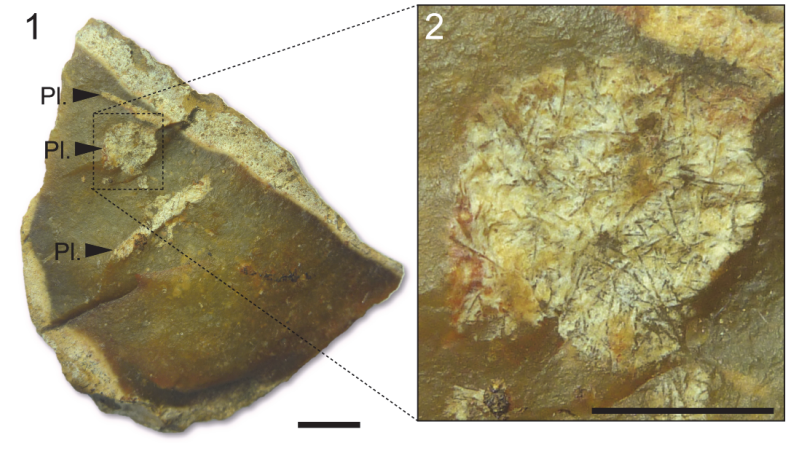

FIGURE 10. 1, Upper Cretaceous fragment of flint from Moragne bearing foliar remains of terrestrial plants, IGR-PAL-2816. 2, Detail of the surface of plant remains showing abundant sponge spicules. Abbreviation: PI: plant remains. Scale bars: $1,1 \mathrm{~cm} ; 2,0.5 \mathrm{~cm}$.

main phase of weathering, were mineralized (at least partially) during the earliest stages of the diagenesis.

Deposits showing mixing of non-contemporaneous fossils in a single bed are called "time-averaged deposits" (Walker and Bambach, 1971). As demonstrated by many authors (e.g., Fürsich and Aberhan, 1990; Kidwell and Holland, 2002; Bush et al., 2002), such deposits are commonly observed in marine environments. However, they are less documented in context of continental weathering. Commonly, the main factors causing time-averaged deposits are biological (e.g., biogenic reworking and bioturbation) and sedimentological (currents and low sediment input produce erosion, winnowing, reworking, bypassing of sediment and transport). Here, the alterites from Moragne is an uncommon example of long-term time-averaged deposits caused by compaction and selective dissolution of matrix during late weathering period mainly controlled by climatic events.

\section{ACKNOWLEDGEMENTS}

We thank the European Synchrotron Radiation Facility (ESRF) and particularly the ID19 beamline for the beam time and the material support. We thank P. Tafforeau who provided useful help during tomographic experiments. We thank J. Hilton and C. Strullu-Derrien for their constructive reviews on the manuscript. We are greatly indebted to G. Breton and J.-P. Platel for the useful discussion about sponges and rudists. This paper is a contribution to the research program SILVE (2012-2018) of the UMR CNRS 6118 Géosciences (Universite Rennes I) and the project EC-412 financed by the ESRF. J.-D.M. and M.L. received financial support from the CNRS-UMR6118.

\section{REFERENCES}

Agassiz, L. and Desor, E. 1847. Catalogue raisonné des familles, des genres et des espèces de la classe des échinodermes. Annales des Sciences Naturelles, 8:1-167.

Alvarez-Ramis, C., Biondi, E., Desplats, D., Hughes, N.F., Koeniguer, J.C., Pons, D., and Rioult, M. 1981. Les végétaux (macrofossiles) du Crétacé moyen de l'Europe occidentale et du Sahara. Végétations et paléoclimats. Cretaceous Research, 2:339-359. https://doi.org/ 10.1016/0195-6671(81)90022-7

Berthelin, M. and Pons, D. 1999. Signification des caractères partagés entre Bennettitales et Cycadales. Implications de la découverte d'une Cycadale nouvelle du Cénomanien de l'Anjou (France). Annales de Paléontologie, 85:227-239. https://doi.org/10.1016/S07533969(00)87930-6

Bourgueil, B., Moreau, P., Gabet, C., l'Homer, A., and Vouvé, J. 1972. Notice Explicative, Carte Géologique au 1/50 000, Feuille de Rochefort (709). Bureau de Recherches Géologiques et Minières, Orléans.

Bower, F.O. 1899. Studies in the morphology of spore-producing members IV. The Leptosporangiate ferns. Philosophical Transactions of the Royal Society B, 192:29 138.

Bush, A.M., Powell, M.G., Arnold, W.S., Bert, T.M., and Daley, G.M. 2002. Time-averaging, evolution, and morphologic variation. Paleobiology, 28:9-25. https://doi.org/10.1666/00948373(2002)028\%3C0009:taeamv\%3E2.0.co;2

Callen, R.A. 1983. Late Tertiary 'grey billy' and the age and origin of surficial silicifications (silcrete) in South Australia. Journal of the Geological Society of Australia, 30:393-410. https://doi.org/10.1080/00167618308729265 
Caux, S. 2015. Du Territoire d’Approvisionnement au Territoire Culturel. Pétroar-chéologie et Techno-économie du Silex Grain de Mil Durant l'Aurignacien dans le Sud-ouest de la France. Unpublished PhD Thesis. University of Bordeaux, Bordeaux, France.

Daniou, P. 1978. Les provinces détritiques des confins de la Saintonge et du Périgord. Norois, 97-98:25-51. https://doi.org/10.3406/noroi.1978.3675

Daniou, P. 1982. Quelques aspects de la géomorphologie des pays sableux des confins des Charentes et du Périgord. Norois, 113:155-162. https://doi.org/10.3406/noroi.1982.4028

Daniou, P. 1984. Etude géomorphologique du pays au bois de la Nizonne entre Dordogne et Charente. Revue Géographique des Pyrénées et du Sud-Ouest, 55:71-84. https://doi.org/ 10.3406/rgpso.1984.4606

Del Fueyo, G.M., Archangelsky, S., Llorens, M., and Cúneo, R. 2008. Coniferous ovulate cones from the lower Cretaceous of Santa Cruz province, Argentina. International Journal of Plant Sciences, 169:799-813. https://doi.org/10.1086/533608

Dewolf, Y. 1970. Les argiles à silex: paléosols ou pédolithes. Bulletin de l'Association Française pour l'Étude du Quaternaire, 7:117-119. https://doi.org/10.3406/quate.1970.1153

Dybowski, W. 1877. Die Chaetitiden der ostbaltischen Silur-Formation. Russisch-Kaiserliche Mineralogische Gesellschaft zu St. Petersburg Verhandlungen, 14:1-134.

Endlicher, S. 1847. Conspectus Coniferrarum Fossilium. Scheitlin \& Zollikofer, Sangalli.

Fürsich, F.T. and Aberhan, M. 1990. Significance of time-averaging for palaeocommunity analysis. Lethaia, 23:143-152. https://doi.org/10.1111/j.1502-3931.1990.tb01355.x

Gallois, R.W. 2009. The origin of the Clay-with-flints: the missing link. Geoscience in South-West England, 12:153-161.

Girard, V., Breton, G., Perrichot, V., Bilotte, M., Le Loeuff, J., Nel, A., Philippe, M., and Thévenard, F. 2013. The Cenomanian amber of Fourtou (Aude, Southern France): taphonomy and palaeoecological implications. Annales de Paléontologie, 99:301-315. https:/ /doi.org/10.1016/j.annpal.2013.06.002

Gorozhankin, I.N. 1904. Lektsii po morfologii i sistematike archegonialnykh rastenij. II. Pteridophyta. I. Archispermae. A.I. Mamontov, Moscow.

Halle, T.G. 1913. The Mesozoic Flora of Graham Land. Lithographisches Institut des Generalstabs, Stockholm, Sweden.

Harris, T.M. 1979. The Yorkshire Jurassic Flora V. Coniferales. British Museum (Natural History), London, England.

Herman, A.B. and Kvaček, J. 2010. Late Cretaceous Grünbach Flora of Austria. Naturhistorisches Museum Wien, Wien. https://doi.org/10.1016/j.cretres.2010.05.005

Kidwell, S.M. and Holland, S.M. 2002. The quality of the fossil record: implications for evolutionary analyses. Annual Review of Ecology and Systematics, 33:561-588. https:// doi.org/10.1146/annurev.ecolsys.33.030602.152151

Kvaček, J. 1999. New data and revision of three gymnosperms from the Cenomanian of Bohemia - Sagenopteris variabilis (Velenovský) Velenovský, Mesenea bohemica (Corda) comb. nov. and Eretmophyllum obtusum (Velenovský) comb. nov. Acta Musei Nationalis Pragae Historia Naturalis Series B, 55:15-24.

Kvaček, J. 2000. Frenelopsis alata and its microsporangiate and ovuliferous reproductive structures from the Cenomanian of Bohemia (Czech Republic, Central Europe). Review Palaeobotany and Palynology, 112:51-78. https://doi.org/10.1016/s0034-6667(00)00035-x

Lamarck, J.B. 1819. Histoire Naturelle des Animaux sans Vertèbre. Published by the author, Paris, France.

Laporte, L., Marchand, G., Sellami, F., Oberlin, C., and Bridault, A. 2000. Les occupations mésolithiques et du Néolithique ancien sur le site de la Grange à Surgères (CharenteMaritime). Revue Archéologique de l'Ouest, 17:101-142. https://doi.org/10.3406/ rao.2000.1104

Lecointre, G. and Carpentier, A. 1938. Sur les empreintes de Frenelopsis du Cénomanien provenant du forage de Monts-sur-Guesnes (Vienne). Bulletin de la Société Géologique de France, 5:583-586.

Lyckegaard, A., Johnson, G., and Tafforeau, P. 2011. Correction of ring artifacts in X-Ray tomographic images. International Journal of Tomography and Statistics, 18:1-9.

Macé-Bordy, J. 2007. Révision des rudistes crétacés (Bivalvia) de la Paléontologie française d'Alcide d'Orbigny. Première partie. Annales de Paléontologie, 93:1-26. https://doi.org/ 10.1016/j.annpal.2007.06.001 
Miramand, P., Dépré, E., and Néraudeau, D. 2017. Rudistes du Cénomanien de CharenteMaritime. Fossiles, 10:48-53.

Mirone, A., Brun, E., Gouillart, E., Tafforeau, P., and Kieffer, J. 2014. The PyHST2 hybrid distributed code for high speed tomographic reconstruction with iterative reconstruction and a priori knowledge capabilities. Nuclear Instruments and Methods in Physics Research Section B: Beam Interactions with Materials and Atoms, 324:41-48. https://doi.org/10.1016/ j.nimb.2013.09.030

Moreau J.-D., Arvaux, J., and Hérisson, D. 2018. Turonian flora from the fossiliferous flints of Châtellerault (western France). Comptes Rendus Palevol, 17:435-442. https://doi.org/ 10.1016/j.crpv.2017.08.001

Moreau, J.-D., Néraudeau, D., Gomez, B., Tafforeau, P., and Dépré, E. 2014a. Plant inclusions from the Cenomanian flints of Archingeay-Les Nouillers, western France. Lethaia, 47:313322. https://doi.org/10.1111/let.12049

Moreau, J.-D., Néraudeau, D., Gomez, B., Tafforeau, P., and Dépré, E. 2014b. Inclusions of conifers, echinoids, foraminifers and sponges in flints from the Cenomanian of CharenteMaritime (France): contribution of synchrotron microtomography. Comptes Rendus Palevol, 13:455-461. https://doi.org/10.1016/j.crpv.2014.03.007

Moreau, J.-D., Néraudeau, D., Philippe, M., and Dépré, E. 2017. Albian flora from Archingeay (Charente-Maritime): comparison and synthesis of Cretaceous meso- and macroremains from the Aquitain Basin (southwestern France). Geodiversitas, 39:729-740. https://doi.org/ $10.5252 / g 2017 \mathrm{n} 4 \mathrm{a} 5$

Moreau, J.-D., Néraudeau, D., Platel, J.-P., and Ravon, A.-L. 2016. Fossiliferous flints (marine invertebrates and terrestrial plants) from the Upper Cretaceous of Claix (Charente). Annales de Paléontologie, 102:103-116. https://doi.org/10.1016/j.annpal.2016.05.003

Moreau, J.-D., Néraudeau, D., Tafforeau, P., and Dépré, E. 2015. Study of the histology of leafy axes and male cones of Glenrosa carentonensis sp. nov. (Cenomanian flints of CharenteMaritime, France) using synchrotron microtomography linked with palaeoecology. PLoS ONE, 10(8):e0134515. https://doi.org/10.1371/journal.pone.0134515

Néraudeau, D. 2004. Les silex fossilifères du nord du littoral charentais et leur utilisation au Paléolithique. Bulletin de l'Association Manche Atlantique pour la Recherche Archéologique dans les lles, 17:5-16.

Néraudeau, D. 2011. Les échinides des silex sénoniens de l'archipel charentais (CharenteMaritime, Sud-Ouest de la France): implications biostratigraphiques et paléogéographiques. Annales de Paléontologie, 97:99-111. https://doi.org/10.1016/j.annpal.2011.10.003

Néraudeau, D. 2012. Periaster undulatus et l'origine charentaise des échinides schizastéridés. Annales de la Société des Sciences Naturelles de Charente-Maritime, 10:315-323.

Néraudeau, D. 2014. Origine géologique des silex à plantes de Torsac (Charente). Annales des Sciences Naturelles de Charente-Maritime, 10:459-473.

Néraudeau, D., Allain, R., Ballèvre, M., Batten, D.J., Buffetaut, E., Colin, J.-P., Dabard, M.P., Daviero-Gomez, V., El Albani, A., Gomez, B., Grosheny, D., Le Loeuff, J., Leprince A., Martín-Closas, C., Masure, E., Mazin, J.-M., Philippe, M., Pouech, J., Tong, H., Tournepiche, J.-F., and Vullo, R. 2012. The Hauterivian-Barremian lignitic bone bed of Angeac (Charente, south-west France): stratigraphical, palaeobiological and palaeogeographical implications. Cretaceous Research, 37:1-14. https://doi.org/10.1016/j.cretres.2012.01.006

Néraudeau, D. and Moreau, P. 1989. Paléoécologie et paléobiogéographie des faunes d'échinides du Cénomanien nord-aquitain (Charente-Maritime, France). Geobios, 22:293324. https://doi.org/10.1016/S0016-6995(89)80134-2

Néraudeau, D., Redois, F., Ballèvre, M., Duplessis, B., Girard, V., Gomez, B., Daviero-Gomez, V, Mellier, B., and Perrichot, V. 2013a. L'ambre cénomanien d'Anjou: stratigraphie et paléontologie des carrières du Brouillard et de Hucheloup (Ecouflant, Maine-et-Loire). Annales de Paléontologie, 99: 361-374. https://doi.org/10.1016/j.annpal.2013.10.001

Néraudeau, D., Saint-Martin, S., Batten, D., Colin, J.-P., Daviero-Gomez, V., Girard, V., Gomez, B., Nohra, Y., Polette, F., Platel, J.-P., Saint-Martin, J.-P., Videt, B., and Vullo, R. 2016. Palaeontology of the late Turonian paralic deposits from the Sainte-Mondane Formation (Dordogne, SW France). Geologica Acta, 14:53-69. https://doi.org/10.1344/ GeologicaActa2016.14.1.5

Néraudeau, D., Thierry, J., and Moreau, P. 1997. Variation in echinoid biodiversity during the Cenomanian-early Turonian transgressive episode in Charentes (France). Bulletin de la Société Géologique de France, 168:51-61. 
Néraudeau, D., Vullo, R., Gomez, B., Girard, V., Lak, M., Videt, B., Dépré, E., and Perrichot, V. 2009. Amber, plants and vertebrate fossils from the Lower Cenomanian paralic facies of Aix Island (Charente-Maritime, SW France). Geodiversitas, 31:13-27. https://doi.org/10.5252/ g2009n1a2

Néraudeau, D., Vullo, R., Gomez, B., Perrichot, V., and Videt, B. 2005. Stratigraphie et paléontologie (plantes, vertébrés) de la série margino-littorale Albien terminal - Cénomanien basal de Tonnay-Charente (Charente-Maritime, France). Comptes Rendus Palevol, 4:79-93. https://doi.org/10.1016/j.crpv.2004.11.008

Néraudeau, D., Vullo, R., and Mazan, P. 2013b. Fossiles de la Préhistoire Charentaise. Le Croix Vif, Saintes.

Paganin, D., Mayo, S.C., Gureyev, T.E., Miller, P.R., and Wilkins, S.W. 2002. Simultaneous phase and amplitude extraction from a single defocused image of a homogeneous object. Journal of Microscopy, 206:33-40. https://doi.org/10.1046/j.1365-2818.2002.01010.x

Saint-Martin, J.-P., Saint-Martin, S., and Néraudeau, D. 2013. L'ambre associé aux lignites cénomaniens du Sarladais (Dordogne, SO France). Annales de Paléontologie, 99:289-300. https://doi.org/10.1016/j.annpal.2013.07.001

Sanchez, S., Ahlberg, P.E., Trinajstic, K., Mirone, A., and Tafforeau, P. 2012. Three dimensional synchrotron virtual paleohistology: A new insight into the world of fossil bone microstructures. Microscopy and Microanalysis, 18:1095-1105. https://doi.org/10.1017/S1431927612001079

Srinivasan, V. 1992. Two new species of the conifer Glenrosa from the Lower Cretaceous of North America. Review Palaeobotany and Palynology, 72:245-255. https://doi.org/10.1016/ 0034-6667(92)90029-G

Sternberg, K.M. 1838. Versuch einer geognostisch-botanischen Darstellung der Flora der Vorwelt. Volumes 7-8. Regensburg und Prag, Leipzig.

Tafforeau, P., Boistel, R., Boller, E., Bravin, A., Brunet, M., Chaimanee, Y., Cloetens, P., Feist, M., Hoszowska, J., Jaeger, J.-J., Kay, R.F., Lazzari, V., Marivaux, L., Nel, A., Nemoz, C., Thibault, X., Vignaud, P., and Zabler, S. 2006. Applications of X-ray synchrotron microtomography for nondestructive 3D studies of paleontological specimens. Applied Physics A, Materials Science \& Processing, 83:195-202. https://doi.org/10.1007/s00339-0063507-2

Valentin, X., Gomez, B., Daviero-Gomez, V., Charbonnier, S., Ferchaud, P., Kirejtshuk A., Licht, A., Néraudeau, D., Vullo, R., and Garcia, G., 2014. Plant-dominated assemblage and invertebrates from the Lower Cenomanian of Jaunay-Clan, south-western France. Comptes Rendus Palevol, 13:443-454. https://doi.org/10.1016/j.crpv.2014.04.001

Walker, K.R. Bambach, R.K. 1971. The significance of fossil assemblages from fine-grained sediments: time-averaged communities. Geological Society of America Abstracts with Programs, 3:783-784.

Watson, J. and Fisher, H.L. 1984. A new conifer genus from the Lower Cretaceous Glen Rose Formation, Texas. Palaeontology, 77:719-727.

Zhou, Z., Thévenard, F., Barale, G., and Guignard, G. 2000. A xeromorphic conifer from the Cretaceous of East China. Palaeontology, 43:561-572. https://doi.org/10.1111/j.00310239.2000.00140.x 